\title{
"Civil participation in decision-making on waste management at the local authorities level"
}

\begin{tabular}{|c|c|}
\hline \multirow{5}{*}{ AUTHORS } & Andrius Stasiukynas (D https://orcid.org/0000-0002-2937-241X \\
\hline & Vainius Smalskys (D https://orcid.org/0000-0002-2980-792X \\
\hline & $\begin{array}{l}\text { Arvydas Survila } \\
\text { Volodimyr Yermachenko (D https://orcid.org/0000-0002-5779-3967 }\end{array}$ \\
\hline & Nataliia Gavkalova (D https://orcid.org/0000-0003-1208-9607 \\
\hline & R http://www.researcherid.com/rid/U-6771-2017 \\
\hline ARTICLE INFO & $\begin{array}{l}\text { Andrius Stasiukynas, Vainius Smalskys, Arvydas Survila, Volodimyr } \\
\text { Yermachenko and Nataliia Gavkalova (2020). Civil participation in decision- } \\
\text { making on waste management at the local authorities level. Problems and } \\
\text { Perspectives in Management, 18(1), 438-448. doi:10.21511/ppm.18(1).2020.38 }\end{array}$ \\
\hline DOI & http://dx.doi.org/10.21511/ppm.18(1).2020.38 \\
\hline RELEASED ON & Tuesday, 07 April 2020 \\
\hline RECEIVED ON & Sunday, 05 January 2020 \\
\hline \multirow[t]{2}{*}{ ACCEPTED ON } & Friday, 20 March 2020 \\
\hline & (c) EY \\
\hline LICENSE & $\begin{array}{l}\text { This work is licensed under a Creative Commons Attribution } 4.0 \text { International } \\
\text { License }\end{array}$ \\
\hline JOURNAL & "Problems and Perspectives in Management" \\
\hline ISSN PRINT & $1727-7051$ \\
\hline ISSN ONLINE & $1810-5467$ \\
\hline PUBLISHER & LLC "Consulting Publishing Company "Business Perspectives" \\
\hline FOUNDER & LLC "Consulting Publishing Company "Business Perspectives" \\
\hline
\end{tabular}

NUMBER OF REFERENCES

35
NUMBER OF FIGURES

1

\section{E=-}

NUMBER OF TABLES

1

(C) The author(s) 2022. This publication is an open access article. 


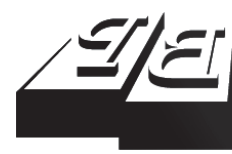

\section{BUSINESS PERSPECTIVES}

9

LLC "CPC "Business Perspectives" Hryhorii Skovoroda lane, 10, Sumy, 40022, Ukraine www.businessperspectives.org
Received on: $5^{\text {th }}$ of January, 2020 Accepted on: $20^{\text {th }}$ of March, 2020 Published on: $7^{\text {th }}$ of April, 2020

(C) Andrius Stasiukynas, Vainius Smalskys, Arvydas Survila, Volodimyr Yermachenko, Nataliia Gavkalova, 2020

Andrius Stasiukynas, Ph.D., Professor, Director of Institute of Public Administration, Mykolas Romeris University, Lithuania

Vainius Smalskys, Ph.D., Professor, Dean, Faculty of Public Governance, Mykolas Romeris University, Lithuania.

Arvydas Survila, Ph.D., Associate Professor, Faculty of Public Governance, Mykolas Romeris University, Lithuania.

Volodimyr Yermachenko, Doctor of Economic Sciences, Professor, Vicerector for scientific and pedagogical work, Simon Kuznets Kharkiv National University of Economics, Ukraine.

Nataliia Gavkalova, Doctor of Economic Sciences, Professor, Head of Department, Faculty of Economy and Law, Department of Public Administration and Regional Economy, Simon Kuznets Kharkiv National University of Economics, Ukraine. (Corresponding author)
Andrius Stasiukynas (Lithuania), Vainius Smalskys (Lithuania), Arvydas Survila (Lithuania), Volodimyr Yermachenko (Ukraine), Nataliia Gavkalova (Ukraine)

\section{CIVIL PARTICIPATION IN DECISION-MAKING ON WASTE MANAGEMENT AT THE LOCAL AUTHORITIES LEVEL}

\begin{abstract}
Civil participation is the main component of effective governance. The topicality of this paper lies in civil participation in decision-making defined by the principles of "new public governance" of the 21 st century. This study aims to analyze the impact of civil participation in decision-making on waste management at the municipal level. In this work, the following aspects were considered: theoretical assumptions of civil participation; civil participation in the activities of institutions responsible for environmental protection; issues regarding the development of opportunities of citizens' involvement in municipal waste management. The article is devoted to the theoretical assumptions about civil participation, theoretical model of analysis, and activity of institutions. To develop a theoretical model of analysis, a classification of civil participation was carried out. Among the methods used, one can mention the questionnaire. The analysis was focused on a legal basis for the activity of institutions; the actual activity of in stitutions and survey of representatives of the national environmental authorities in Lithuania. The results showed that currently there is no mechanism in Lithuania to ensure civil participation in municipal waste management. Civil participation is still formal and limited. Overall, citizens are informed about the decisions made, but they do not participate actively in decision-making. The analysis of civil participation capacity in waste management leads to the conclusion that Lithuania has no single mechanism to ensure civil participation in waste management. To enhance civil participation in decision-making on waste management, it is suggested to set up a council where the representatives of civil population are delegated.
\end{abstract}

\section{Keywords \\ municipal, participation, representatives, wastes management, environmental, mechanism, decision-making}

JEL Classification O13, H70, K10

\section{INTRODUCTION}

After having obtained independence, Lithuania modernized its public governance according to the Western standards. Nevertheless, civil participation in decision-making is hardly advanced in most of public governance spheres. Civil participation in political decision-making is defined by the principles of "new public governance" in the 21st century. This public governance modernization includes different forms of partnership between citizens and public authorities, such as community engagement in resolution of public issues, networking, and various approaches to resolution of public issues (e.g., social, poverty) (McQuid, 2010).

Waste management is a social, economic, and environmental problem. For this reason, participation of public and non-governmental sectors in its solution is an important factor of sustainable management of the waste produced. Large quantities of waste are produced and transported to landfills, with extremely negative impacts on greenhouse emissions, soils, water, and human health. For this reason, waste man- 
agement is an important issue in a political agenda. Waste management is a global phenomenon, and in the case of the European Union (EU), the Commission requires more effort from the member states. For several years, the EU countries' policy is focused on the principle "take, produce, throw away". However, this idea does not match with modern society values (Skorupskaite \& Junevičius, 2017). Till the end of the 20th century, the waste management policy in Lithuania was to collect and dispose of it in landfills, which increased with society consumption. For this reason, more effort was made in waste sorting and recycling, and a new approach was needed to solve this issue (Ratezanu \& Pascu, 2015). Waste increase and increase of consumption patterns contributed to the pressure on natural resources and environmental degradation. In this context, much effort was posed on waste prevention, and recycling started to be an important aspect in circular economy concept. To solve waste management problem, a new public governance attitude is needed (Podgaiskytè, 2016).

Waste management policy was focused on regulation and reduction of waste flows. To solve waste management problems, it is important to regulate waste disposal. Control of waste quantity is related not only to generated waste management but also environmental protection and preservation of natural resources (Skorupskaite \& Junevičius, 2017). Civil perception and participation in waste management is a fundamental step to sustainability since the impacts of landfills on the environment such as greenhouse emissions, soil, and water pollution, landscape degradation, and public health are very high. Despite this, the majority of population in Lithuania is not aware of this issue. To have the maximum environmental, social, and economic benefit from waste management and to successfully implement a circular economy model, it is important to implement effective measures to monitor waste management (Bivainis \& Podgaiskyte, 2016).

\section{LITERATURE REVIEW}

Many scientists have been involved in environmental decision-making at the local government level, namely the study on civil participation in urban waste management discussion by Ratezanu and Pascu (2015), which offers a new approach to address waste management. Bivainis and Podgaiskytė (2010) focus on reducing and regulating waste streams. Skorupskaitè and Junevičius (2017) consider not only waste reduction but also environmental protection and conservation. Ferreira, Monedero, Luís Martí, Aliaga, Hortal, and Dobón López (2009) look at the problems of recycling from an economic point of view, changing the way (re-arranging) the way, and it can help to save the resources. Bartoleto (2015), in relation to civil participation in environmental decision-making at the local government level, uses the so-called three $\mathrm{R}$ - reduce, reuse, and recycle. Tugov, Eskin, Litun, and Fedorov (n.d.) propose the use of waste incineration plants, which will be included in the integrated waste management system along with enterprises for the recycling of certain materials (glass, metal, paper, etc.).

In a broad sense, civil participation can be defined as a process during which citizens who have not been officially elected or assigned to make decisions participate along with official persons in the development of an agenda and (or) decision-making on relevant issues or in relation to public policy, which affect their interests (Rowe \& Frewer, 2005). Civil participation improves policy development and decision-making quality (authorities can avail of a broad range of information resources, prospects, and potential decisions); ameliorates and speeds up the interaction between authorities and citizens; increases responsibility, transparency, and builds people's trust (Bovaird \& Loffler, 2003).

It should be stressed that the most important functions of civil participation are as follows: 1) it helps ensure the response of public governance institutions and accountability to citizens; 2 ) it creates conditions for people and groups to exert influence on decisions that affect them, enhancing their competence and skills; 3) it makes a democratic system stable. Besides, civil participation strengthens the social structure of society because it establishes inter-personal relationships, develops an understanding of each other, and provides citizens with the opportunity to act not only in their personal interest but also in the interest of the community (Petukienè \& Tijūnaitiené, 2007). 
Governance institutions play an important role in the implementation of waste management policies. Most of the waste flow is from municipalities, and the greatest part of the waste is managed at this level; thus, it is important to realize civil participation in decision-making and contribution to solve this problem at the level of administration (Bivainis \& Podgaiskyte, 2010).

\section{GENERALIZATION OF THE MAIN STATEMENTS}

Based on the model of the theoretical classification presented in "A Ladder of Citizen Participation" (Arnstein, 1969), several indicators were developed to classify different types of participation. The study analyzes the principles of civil participation in Lithuania in the field of municipal waste management, the published strategic plans and reports for the last five years. To find out the attitude of the national level institutions responsible for the environmental protection towards the idea of public, community, or household engagement in municipal waste management issues, the high-level representatives (one from each institution) of the Committee on Environment Protection of Lithuanian Parliament, the Department of Waste Management of the Ministry of Environment and Kaunas and Panevežys Regional Environmental Protection Department of Ministry of Environment were interviewed in Autumn 2017 on the following groups of open questions: 1) public information; 2) obstacles to citizens' (and consumers') involvement and 3) improvement of citizens' engagement.

Civil participation is carried out in different stages. Streamlining of the government structure and decision-making process is often associated with different forms of civil (community) participation in politics. One of the most popular and first community participation typologies was "A Ladder of Citizen Participation" classification developed by Arnstein (1969) (Table 1). As can be seen from the public participation typologies, citizen participation usually starts with the stage of public information (education). The methods applied later demonstrate an increasingly higher citizens' involvement in decision-making where it reaches permanent participation and even control. It should be noted that a "higher" step does not necessarily mean "better" or "more effective" as participation forms must meet the goals. Arnstein (1971) notes that assumptions for public participation provide citizens with powers to perform the allocation of public goods provided to society and their management, taking into account the real needs. According to Bovaird and Loffler (2003), civil engagement and participation in decision-making is the main component of effective governance.

The analysis of the issue of civil participation in the governance of environmental protection leads to the question of what criteria can define the potential process participants. Decision-making must be attended by persons that have vested interest related to the decision. The interested persons or the stakeholders might be defined as a group or individuals that might influence the pursuance of the organization's goals, or which influence might be exerted so as to reach corporate goals (Schlossberg \& Shuford, 2005). Not all members of the general public can be described as stakeholders in certain situations, just like not all stakeholders can be considered the public. From a practical point of view, stakeholders are often (but not always) the representatives of one part of society. The waste management sector under consideration can feature a few categories of persons that participate and (or) are interested in the activities of municipal waste management or public policy development:

household consumers and their representatives that care about the service being provided in a reliable (uninterrupted) manner and at a reasonable cost. Service consumers can be individual households and legal entities. Both these groups can be the members of associations or any other compounds uniting them;

- municipal waste collection service providers and other representatives of the sector. Municipal waste collection service providers seek to make a profit from their activities and to increase their earnings as much as possible. It should be noted that the aims of this category of stakeholders to some degree conflict with the aims of consumers; 
Table 1. Stages of public participation

Source: Based on Arnstein (1969).

\begin{tabular}{|c|c|}
\hline Stage & Stage and its description \\
\hline Citizen power & $\begin{array}{l}\text { 8. Citizen control means the absolute majority of citizens' votes in making decisions in public policy development } \\
\text { and approval institutions. The citizen control step is achieved where citizens have an absolute majority in public } \\
\text { policy development and implementation in the institutions when decisions are made. This majority guarantees } \\
\text { the capability of citizens to fully manage programs or institutions and have a considerable effect on public policy } \\
\text { development. This step is not always effective in practice - in most cases, this mechanism is more expensive but } \\
\text { less effective; it promotes separatism; creates conditions for the groups of minorities to have a bigger influence on } \\
\text { decision-making than the unorganized majority, etc. } \\
\text { 7. Delegation of powers: citizens have a determinant number of votes in making decisions compared to official } \\
\text { government representatives. The stage of delegated power means a situation where citizens have a decisive number } \\
\text { of votes in making decisions compared to official government representatives. The latter must enter into negotiation } \\
\text { with citizens so as to reduce the pressure from them. } \\
\text { 6. Partnership (collaboration): the powers of government are divided among citizens and the representatives of } \\
\text { official government through negotiations. They cooperate in the fields of planning and decision-making. In the stage } \\
\text { of partnership, the powers of government are divided between the citizens and the representatives of official power } \\
\text { who cooperate in the planning and decision-making areas. The following tools are often applied: joint councils } \\
\text { of public policy development, planning committees, special workgroups designated to solve certain situations. } \\
\text { Partnership will work effectively where the community is well-organized, its leaders are accountable, and where it } \\
\text { has sufficient resources to pay to its representatives and hire required specialists. }\end{array}$ \\
\hline & $\begin{array}{l}\text { 5. Biasing (others) in favor of one's personal benefit: a few more "convenient" citizens are involved in different } \\
\text { advisory councils, commission, etc., giving them the power of vote, however, reserving the right of final decision to } \\
\text { the representatives of government. Seeking to bias citizens for their own benefit, the representatives of government } \\
\text { engage several "convenient" citizens in various advisory councils, commissions, etc., reserving the right of the final } \\
\text { decision to the representatives of government. If the involved citizens are not accountable to their community and } \\
\text { have no sufficient levers of influence, such involvement is often nominal only. } \\
\text { 4. Consulting: the aim is to know what the public opinion is. The most frequent tools of this step: opinion polls, } \\
\text { meetings with communities, public questionnaires. Consulting with citizens allows knowing what the society thinks; } \\
\text { however, it is important to apply other mechanisms so that their opinion could be taken into account. The most } \\
\text { frequent measures of the consulting stage: opinion polls, meetings with communities, and public questionnaires. } \\
\text { To adopt such measures, it is important to prepare properly: survey participants often do not know about the } \\
\text { possibilities to facilitate their living conditions or give additional benefit, and the participation is measured by the } \\
\text { number of completed questionnaires or the length of the list of meeting participants. } \\
\text { 3. Informing: informing citizens about their rights, obligations, and choices without feedback from citizens. First } \\
\text { steps are made by creating conditions for community members to share information, however, without feedback, } \\
\text { citizens' opinions remain commendatory only, and the involvement of the community is nominal only. }\end{array}$ \\
\hline Non-participation & $\begin{array}{l}\text { 2. Therapy (treating the outcomes of disease): the aim is to adapt citizens to the existing situation, curing their } \\
\text { inability to adjust instead of making an influence on citizens. This stage is called therapy because it is related } \\
\text { with citizens' disability and their treatment by way of group therapy method. In the stage of therapy, all attempts } \\
\text { are made to adapt citizens to the existing situation, to cure their inability to adjust, instead of influencing the } \\
\text { environment unfavorable to citizens. } \\
\text { 1. Manipulating the public: citizens are familiarized with the existing programs; they are explained that these } \\
\text { programs are related to citizens' needs, and it is pointed out what role should be played by them [citizens]. This stage } \\
\text { focuses on creating conditions for the rulers to "teach" or "cure" instead of engaging citizens in the planning process } \\
\text { or conditional programs, and this is done through involving citizens' representatives in advisory groups, committees, } \\
\text { etc. }\end{array}$ \\
\hline
\end{tabular}

- public authorities responsible for the development of public policy and its implementation. Public authorities seek to harmonize the interests of the aforementioned stakeholders and take care of them. To this end, a system of the institution has been designed, and functions have been allocated.

All the above-mentioned groups often have different interests. Moreover, it should be emphasized that the level of civil participation shows the ex- tent of influence that society has on the stage of the governance process.

The public can be engaged in different phases of public governance: by formulating problems, setting priorities, or versions of solutions, by making decisions, implementing, or assessing them. Situation analysis and the drawn up alternative solutions are usually directed to the institutions of the executive authority responsible for the environmental protection sector. Bearing responsibili- 
ty for this stage of the governance process and taking into consideration the specificity of the issue under consideration, the latter can assign such a task to other institutions based on the subordination principle or purchase such services from other legal or natural persons. Thus, a responsible institution also organizes the identification of public needs. The legislative authority usually makes the main public governance decisions; however, according to the nature of decisions and respective competence, they can also be made by other governance bodies. The pursuance of the decision, given the area of the issue under consideration, is directed to corresponding institutions, which are usually a part of the executive power.

Assumptions for the civil participation in the institutions' activities that develop and implement the policy of municipal waste management sector in Lithuania are made by the main applicable legal acts of the country that define the forms of participation. The legislation of Lithuania has the provision that "all state institutions serve the people" (Law of the Republic of Lithuania on Public Administration, 1999), which leads to the assumption that civil servants must take care of public needs and to put every effort to satisfy such needs effectively. The obligation imposed on civil servants to provide public information to the society (Law of the Republic of Lithuania on Public Information, 1996) establishes the aspiration of public information. The Description of the Procedure for the Strategic Assessment of the Effects of Plans and Programmes (Resolution No. 967 of the Government of the Republic of Lithuania, 2004), territorial planning (Law of the Republic of Lithuania on Territorial Planning, 1995). The law of the Republic of Lithuania on Local Self-Government (2008) provides for various forms of civil participation. It is pointed out that organizations whose competence is determined by the planning organizers are invited for consultation. The latter also plays an important role in determining the way the proposals of the society will be taken into account. The results of the survey are just a recommendation and "they may be referred to when making a decision" (Article 46 of the Law of the Republic of Lithuania on Local Self-Government, 2008). Thus, a mechanism to ensure cooperation among public governance institutions and partnership with citizens when making decisions is not provided (Arnstein, 1969). However, it should be noted that there is a possibility for citizens to challenge the decisions that infringe on the rights and (or) interests of the applicant/claimant.

The institutions that participate in the development of the environmental policy in the municipal waste management sector in Lithuania and their implementation are 1) the Parliament, 2) the Government, and 3) the Ministry of the Environment. The Ministry of the Environment has eight regional departments that are further subdivided into agencies (located in Alytus, Kaunas, Klaipeda, Marijampole, Panevėžys, Šiauliai, Utena, and Vilnius). The State Environmental Protection Authority should also be added, as it aims to control the actions of environmental protection actors in protecting the environment. The analysis of legislation regulating the activities of respective institutions was carried out while examining public involvement in the management of the examined sector.

The Parliament of Lithuania votes the most important legal acts that develop the public policy of the environmental governance sector and set the guidelines for its pursuance. Issues of the sector under consideration are normally supervised by the Committee on Environment Protection of the Parliament, which, having received or drawn up a draft law, announces the deadline for stakeholders to put forward their remarks, comments, and suggestions (The Statute of the Seimas of the Republic of Lithuania, 1999). In accordance to the Statute of the Parliament, open sittings shall be public, and information must be provided to the public; however, no right of vote during public meetings of committees is reserved to the representatives of stakeholders. The Government of Lithuania (Republic of Lithuania Law on Government, 1998) and the Ministry of the Environment (Resolution No. 336 of the Government of the Republic of Lithuania, 2008) draw up draft laws and other regulations related to the activities of the sector under consideration. Legislation regulating the activities of the institutions mentioned above provides the institutions with an option, if required (e.g., when drafting laws, the preparation of which requires specific knowledge) of applying to corresponding organizations, researchers, consumer representatives. 
The State Environmental Protection Authority (Regulations of the State Environmental Protection Authority, 2016) is an agency under the Ministry of the Environment of the Republic of Lithuania whose purpose is to carry out the analysis of waste, product, and package flows, to organize training for the state control officers of the environmental protection and ensure supply of the required working tools.

Regional environmental protection departments exercise state control to ensure legality and law enforcement in the field of environmental protection and the use of natural resources (Regulations of Vilnius Regional Environmental Protection Department, 2016). Although operational rules of these departments stipulate that they consider the proposals of the society and cooperate with the public as well as inform it, the rules provide no mechanisms for consultation with the public or of citizens' involvement in decision-making. Regional environmental protection departments serve as a means of integration of smaller offices (that are distributed on a smaller territorial scale), namely, environmental protection agencies.

\subsection{Analysis of public governance institutions' representatives' survey results}

The representatives of public governance institutions stated that the public was informed sufficiently since all legal acts were publicly available. They emphasized that the task of waste management was assigned to municipalities. For instance, pursuant to the provisions of the Law on Waste Management (1998), the responsibility for legislation governing waste management is started by the Ministry of Environment. Meanwhile, the organization of municipal waste management system is assigned to an institution of local government (e.g., municipality). General information about regulations on the system of municipal waste management is available on the website of the Ministry of Environment. Information about the organization of the system of municipal waste management in a specific municipality can be found on the website of a respective municipality or the website of the regional waste management center. Information to the public is also disseminated in the form of various brochures and other means of mass media (newspapers, magazines, TV programs, radio programs, reports during events and conferences). Under the provision laid down in Paragraph 294 of the National Waste Management Plan for the period 2014-2020 approved by Resolution No. 519 of the Government of the Republic of Lithuania of April 12, 2002 (hereinafter referred to as the "Plan"), the Ministry of Environment must annually before June 1 organize public presentation of the Plan to state institutions that organize waste management and other participants of the waste management system. Information on the implementation of measures of the Plan is annually presented to the society in a public manner.

The results of answers to the questions of group two (Government) showed that representatives of institutions think that the public has the opportunity of getting involved in the discussion on waste management. They argued that civil participation depends on the citizens' initiative. All legal acts and their drafts, which are prepared and approved with respect to municipal waste management, are published in the Legislative Information System (LIS). Using the LIS the public can submit remarks and proposals for the drawn up regulations and, in this way, affect the decision-making on waste management. It would be excellent if municipalities would take into consideration the opinion of residents when they organize waste management plans. Attention should be drawn to the fact that self-government has the freedom of choice when deciding on the organization of municipal waste management. Thus, every municipality can make decisions that are best for its residents.

The answers of the third group (Ministry of the Environment) questions revealed that for the representatives of state institutions, there are all possibilities for the public to take part in the decision-making process, and a civil servant representing the Waste Department of the Ministry of Environment of Lithuania noted that "...it is important that representatives of the public avail of this opportunity properly". The respondents of the survey could not indicate any specific measures for greater involvement or were unable to give any arguments so to motivate citizens to get engaged in the decision-making.

The concerned public governance institutions are obliged to inform the public about the decisions 
made, participants of the public are provided with conditions to participate in public meetings and sittings, there is a possibility to take an interest in public opinion. Nevertheless, it should be noted that information is provided in a limited manner: information is forwarded to mass media and on websites of the concerned institutions. There is no systematic approach for public information and education or for taking into consideration public needs. Public meetings ensure no voting rights. Public opinion is not always recorded in such meetings. The public policy of citizens as consumers is implemented simply focusing on the aspect of complaints' submission and expression of dissatisfaction. Following the analysis of legal grounds governing the activities of state institutions and the survey of representatives of public governance authorities, it became clear that there is no single mechanism in Lithuania to ensure civil participation in the environmental protection, in particular, in the field of municipal waste management, namely, in formulating problems and solving issues that are relevant to the public. The only thing that is done is the simple provision of general information. Although legislation is published in a digital space, civil participation by responding to draft legal acts or by putting forward any remarks is low. The submitted comments, suggestions are just recommendations and impose no obligation to be taken into consideration. National authorities have no measures to directly involve citizens in naming the problems and finding the solutions; the citizens discover the already planned actions.

Thus, according to Arnstein's (1969) typology, the capacity of civil participation in the activities of the Lithuania Parliament is low. The participation can be classified as non-participation (manipulation and therapy), where citizens are informed about decisions and are urged to adapt to the existing changes. Actually, the performance of the Government and Ministry of Environment of Lithuania features minor attributes of citizens' information (education) and consultation (level of symbolic participation). However, these are only formal assumptions that are not considered a form of civil participation (Figure 1).

The public could be involved in the governance of environmental management sector by traditionally developing mechanisms designed for participation by stakeholders (i.e., consumers) and by educating and consulting them. The specificity of the environmental protection sector and the particularities of the public governance bureaucracy determine that those participating must have specific knowledge; thus, the public is less active in the management of this sector. On the other hand,

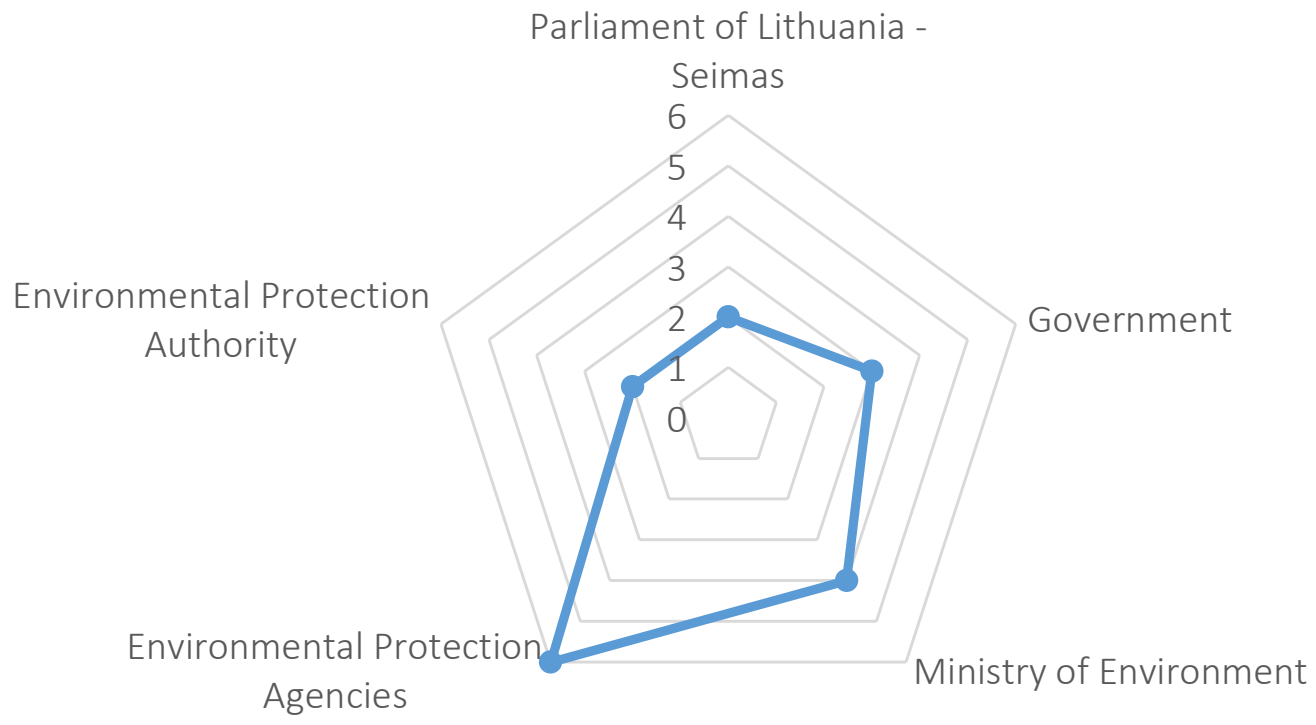

Note: Levels: 1 - Manipulating the public; 2 - Therapy; 3 - Informing; 4 -Consulting; 5 - Biasing (others) in favor of one's personal benefit; 6 - Partnership (collaboration); 7 - Delegation of powers; 8 - Citizen control.

Figure 1. Capacity of civil participation in the activities of national public governance institutions of environmental protection in the field of municipal waste management 
the trends of recent years enable one to assume that citizens could be engaged in policy development and implementation not only as consumers and representatives of the society but also as active participants of the sector.

\section{DISCUSSION}

\subsection{Development of the potentials of citizens' involvement in municipal waste management}

Public participation happens when clear mechanisms of public education and consultation are implemented. Citizens must know what policy is relevant to them, what is being developed, and how and what programs are put into action, what processes are open for civil participation, and what influence they have on them (Government of Canada, 2000). Previous works in similar specific areas (e.g., environmental protection, energy, application of new biotechnologies in food production, etc.) claim that participation is possible only in certain areas (Sh. Tang, Ch. Tang, \& Lo, 2005) and highlight that the public must be necessarily educated. Institutionalized conditions for citizens to express their opinion and make decisions are of no less importance. Thus, a mechanism has to be developed to affect citizens' knowledge, i.e., to educate and inform citizens and provide them with conditions to participate and have an impact on governance processes, i.e., the possibilities of the society and public authority cooperation must be institutionalized.

Frank and Ebdon (2007) examined public participation stages, and listed several ways to inform and educate the public: 1) preparation and dissemination of brochures and posters; 2) advertising; 3 ) social marketing; 4) conference organization and publicity, etc. Increased use of intellectual technology (e.g., online surveys and petitions) has caused the residents to become increasingly active.

Striving to ensure the transparency of their activity, public bodies must inform the society about their operation; however, it is also important that annual reports or any other information were available to the public in an acceptable form and was easily accessible (e.g., would not be intended for the internet users only, etc.). Following the studies on civil involvement in the field of health and environmental protection, the results showed that it is necessary to provide information in an appropriate form and content because this is the only way the public could be properly familiarized and would gain the chance to participate in decision-making. Nevertheless, attention should be drawn to the factor of the specificity of a sector. For instance, there are areas, such as electrical power management, where only a handful of citizens can express their competent opinion. For this reason, the public should be educated appropriately in an accessible manner and with the content adapted for it, taking into consideration the statistical average personal skills and possibilities.

In the analysis of effective regulation, World Bank emphasized not only the possibilities of representatives of the public to express their opinion or to challenge the decisions of institutions but also the importance of advisory (consulting) institutions. Such institutions or councils are set up voluntarily and are composed of consumers, representatives of other stakeholders, experts of the field, and other persons. Advisory councils are particularly relevant in the countries, which have no well-established traditions of representation (World Bank Group, 1997).

The analysis of legal acts governing the activities of national environmental protection authorities of Lithuania and the interviews of the corresponding experts revealed that citizens are not sufficiently involved in the preparation of decision alternatives and in setting their priorities (given the public needs). Also, to achieve greater transparency and accountability in the pursuance of the decisions made, the public should be informed to a greater extent. If required, amendments to the decisions (programs) being implemented should be coordinated.

According to World Bank Group (2007), the highest efficiency is achieved when interests are represented before the decision-making. Key decisions, which express public policy, are made in the Parliament. Meanwhile, the Ministry of Environment is responsible for preparing the most important environmental decisions (draws up draft strategies, draft laws, etc.). The formula- 
tion of problems is directly related to the analysis of public needs. For this reason, it is particularly important to involve the citizens. Usually, the determination of decision versions is related to specialist work. They draft potential versions that are adopted by persons representing the public. Thus, in seeking for a transparent process of public policy development, the authority mentioned above must be most interested in civil participation.

The view that citizens must be provided with the opportunity to evaluate the results and participate in the development of the executive policy since they are "the owners of democratic authority and have the right to assess the results and the effort of the heads of the government" (Ho, 2007). The Ministry of Environment takes care off the implementation of the public policy in the area of municipal waste; therefore, an advisory group of citizens (e.g., council), which can assess the activities and whose relationship with the public is very close, can promote the quality of administration of continuous feedback and inform the society using the relationships of the members of this group.

The research helped reveal that the aspiration to have civil participation based on Arnstein's (1969) classification requires the level of citizens' power; however, the stages of citizens' control and granting of power in pursuance of governance efficien$c y$, as well as given the particularities of the sector under consideration, are not considered superior to the "partnership" stage. To ensure the possibilities of civil participation according to the latter stage, the civil participation measure should be applied, which creates conditions for participating in the decision-making related to specific knowledge without engaging exceptionally competent experts alone.
In practice, several various methods are applied: citizens' advisory groups, citizens' juries, citizens' panels (Arnstein, 1969), and the like. For instance, this measure was successfully applied in various areas that require specific knowledge (food biotechnology issues - in Western Canada; telecommunication and the topic of democracy - Boston, the USA, and elsewhere) (Government of Canada, 2000). Application of this measure requires that a group of representatives of the public is extensively (in social, economic, and other aspects) familiarized with the relevant problems and that experts are invited for consultation. Decisions they make must be comprehensively reasoned; separate conflicting opinions must be described. Such an approach later helps other public governance institutions in making the decisions that reveal the citizens' expectations. The works carried out, analyzing civil participation methods, are not unanimous with regard to the description of these tools (namely different number of participants, duration of application of the measure, etc.). However, in all cases, the focus is a group of people who represent the public and who gain information, negotiate, and make a decision. Members of such a council are elected according to the representation of groups of stakeholders (consumers, electricity sector representatives, representatives of state institutions (of the same or higher hierarchical rank). To ensure the stage of the partnership (based on Arnstein's typology), representatives of consumers should constitute half of all members. Public authorities (in this case, the Ministry of the Environment) must take into account the decisions of the council, and upon the failure to put them into action - present a reasoned explanation. In its work, the council may apply other civil participation approaches as well, e.g., by involving more stakeholders to achieve weightier decisions (e.g., consensus conference, study groups, etc.).

\section{CONCLUSION}

The analysis of the capacity of civil participation in the activities of Lithuanian environmental protection central (national) authority in the area of municipal waste management leads to the conclusion that Lithuania has no single mechanism to ensure civil participation in the environmental protection management area of municipal waste management by naming the problems or solving the issues that are relevant to the general public. Civil participation is rather formal and limited. The national public governance institutions think that citizens' information about the decisions made is sufficient, and legal opportunities for civil participation exist but depend on the level of citizens' activity, not the institutions. 
The respondents were unable to point out how to improve civil participation. The analysis of legal acts governing the activities of national environmental protection management institutions of the Republic of Lithuania and survey of experts revealed that citizens are not sufficiently engaged in the preparation of decision alternatives and in setting their priorities (taking into consideration public needs). To enhance civil participation in decision-making, it is suggested that the Ministry of the Environment set up a council. It is granted that the authority of decision-making and representatives of stakeholders are delegated to it.

\section{AUTHOR CONTRIBUTIONS}

Conceptualization: Vainius Smalskys, Volodimyr Yermachenko, Nataliia Gavkalova.

Data curation: Arvydas Survila, Andrius Stasiukynas.

Formal analysis: Arvydas Survila, Andrius Stasiukynas, Nataliia Gavkalova.

Funding acquisition: Arvydas Survila, Andrius Stasiukynas, Nataliia Gavkalova.

Investigation: Vainius Smalskys, Volodimyr Yermachenko, Nataliia Gavkalova.

Methodology: Vainius Smalskys, Volodimyr Yermachenko, Nataliia Gavkalova.

Project administration: Vainius Smalskys, Volodimyr Yermachenko.

Resources: Arvydas Survila, Andrius Stasiukynas, Nataliia Gavkalova.

Software: Arvydas Survila, Andrius Stasiukynas.

Supervision: Vainius Smalskys, Volodimyr Yermachenko, Nataliia Gavkalova.

Validation: Arvydas Survila, Andrius Stasiukynas.

Visualization: Arvydas Survila, Andrius Stasiukynas.

Writing - original draft: Vainius Smalskys, Arvydas Survila, Andrius Stasiukynas, Nataliia Gavkalova. Writing - review \& editing: Vainius Smalskys, Volodimyr Yermachenko, Nataliia Gavkalova.

\section{REFERENCES}

1. Arnstein, S. R. (1969). A Ladder of Citizen Participation. Journal of the American Planning Association, 35(4), 216-224. https://doi. org/10.1080/01944366908977225

2. Arnstein, S. R. (1971). A Ladder of Citizen Participation. Journal of the Royal Town Planning Institute. Retrieved from https:// www.worldcat.org/title/ladder-ofcitizen-participation-in-the-usa/ oclc/614730228

3. Bartoleto, A. P. (2015). Waste Prevention Policy and Behaviour. New Approaches to Reducing Waste Generation and its Environmental Impacts. In Routledge Studies in Waste Management and Policy. N.Y.: Routledge. Retrieved from https:// www.routledge.com/Waste-Preven tion-Policy-and-Behaviour-NewApproaches-to-Reducing-Waste/ Bortoleto/p/book/9780415737586

4. Bivainis, J., \& Podgaiskytè, V. (2010). Komunalinių atliekų tvarkymo struktūrinè analizè.
Verslas: teorija ir praktika, 11(4), 323-334. https://doi.org/10.3846/ btp. 2010.35

5. Bovaird, T., \& Loffler, E. (2003). Public Management and Governance. Routledge, London, UK. Retrieved from https://trove. nla.gov.au/work/22918171?q\&versi onId $=27801375$

6. Ferreira, B., Monedero, J., Luís Martí, J., Aliaga, C., Hortal, M., \& Dobón López, A. (2009). The Economic Aspects of Recycling. Retrieved from https://www. intechopen.com/books/postconsumer-waste-recycling-andoptimal-production/the-economicaspects-of-recycling

7. Franklin, A. L., \& Ebdon, C. (2007). Democracy, public participation and budgeting. Mutually exclusive or just exhausting? In R. C. Box (Ed.), Democracy and Public Administration (pp. 84-106). New York, USA.

8. Gavkalova, N., \& Zolenko A. (2019). Analysis of the degree of innovative labor activization of the employed population of Ukraine. Development Management, 17(3), 68-74. http://dx.doi.org/10.21511/ dm.17(3).2019.06

9. Government of Canada (2000). The Health Canada Policy Toolkit for Public Involvement in Decision Making. Retrieved from http:// www.hc-sc.gc.ca/ahc-asc/pubs/_ public-consult/2000decision/ index-eng.php

10. Ho, A. T. (2007). Citizen participation in performance measurement. In R. C. Box (Ed.), Democracy and Public Administration (pp. 107-117). New York, USA.

11. Kolodiziev, O. (2013). Formuvannia bahatorivnevoi systemy pokaznykiv finansuvannia innovatsiinoi diialnosti [Formation of multilevel system of indices on innovative activity financing]. Aktualni problemy ekonomiky Actual Problems of Economics, 8, 32-44. (In Ukrainian). Retrieved 
from http://nbuv.gov.ua/UJRN/ ape_2013_8_5

12. Law of the Republic of Lithuania on Local Self-Government. Official Gazette. 2008. No. 113-4290. Retrieved from_http://www3.lrs.lt/ cgi-bin/preps2?a $=327811 \& b=$

13. Law of the Republic of Lithuania on Public Administration. Official Gazette. 1999. No. 60-1945. Retrieved from_http://www3.lrs.lt/ cgi-bin/preps2? $\mathrm{a}=83679 \& \mathrm{~b}=$

14. Law of the Republic of Lithuania on Public Information. Official Gazette. 1996. No. 71-1706. Retrieved from_http://www3.lrs.lt/cgi-bin/ preps $2 ? \mathrm{a}=29884 \& \mathrm{~b}=$

15. Law of the Republic of Lithuania on Territorial Planning. Official Gazette. 1995. No. 107-2391.

16. Law of the Republic of Lithuania on Waste Management. Official Gazette. June 16, 1998. No. VIII787.

17. McQuid, R. (2010). Theory of organizational partnership: partnership advantages, disadvantages and success factor. In S. Osborne (Ed.), The New Public Governance (pp. 125-146). Routledge, London, UK. Retrieved from https://dspace.stir.ac.uk/handle/1893/16959\#.XnTEbuozbcs

18. Petukienè, E., \& Tijūnaitienè, R. (2007). Visuomenés dalyvavimas: socialinio kapitalo, demokratijos ir racionalaus pasirinkimo teorijų apžvalga. Viešoji Politika ir Administravimas, 21, 87-95. (In Lithuanian). Retrieved from https://www.mruni.eu/upload/ iblock/c06/8_a.\%20raipa\%20ir\%20 kt..pdf

19. Podgaiskyte, V. (2011). Darnus atliekų tvarkymo sistemos vertinimas: kriterijų nustatymas. Mokslas - Lietuvosateitis, 3(4), 63-69. https://doi.org/10.3846/ mla.2011.071

20. Ratezanu, I., \& Pascu, B. (2015). The sectorial approach on waste management. University of Economic Studies, Bucharest, Romania. Retrieved from http:// conferinta.academiacomerciala.ro/ CD2015/ARTICOLE/1/THE\%20 SECTORAL\%20APPROACH\%20 ON\%20WASTE\%20MANAGEatezanuPascu.pdf
21. Regulations of the State Environmental Protection Authority approved by Order No. D-144 of the Minister of Environment of the Republic of Lithuania of 26 February 2016 (2016) (edition of Order No. D1-400 of the Minister of Environment of the Republic of Lithuania of 11 May 2017).

22. Regulations of Vilnius Regional Environmental Protection Department of the Ministry of Environment of the Republic of Lithuania approved by Order No. 717 of the Minister of Environment of the Republic of Lithuania of 24 December 2003 (edition of Order No. D1-151 of the Minister of Environment of the Republic of Lithuania of 29 February 2016).

23. Regulations on Public Participation in the Process of Territory Planning. Official Gazette. 1996. No. 90-2099.

24. Republic of Lithuania Law on Government. (1998). Official Gazette. No. 41(1)-1131.

25. Resolution No. 1079 of the Government of the Republic of Lithuania of 18 September 1996 On the Approval of Resolution No. 336 of the Government of the Republic of Lithuania of 9 April 2008 On the Amendment to Resolution No. 1138 of the Government of the Republic of Lithuania of 22 September 1998 "On the Approval of Regulations of the Ministry of Environment of the Republic of Lithuania". Official Gazette. 1998. No. 84-2353; 2002. No. 20-766, No. 60-2464; 2003. No. 11-403, No. 84-3834; 2004. No. 127-4564, No. 167-6131

26. Resolution No. 967 of the Government of the Republic of Lithuania of August 18, 2004 on the Approval of the Description of Procedure for the Strategic Assessment of the Effects of Plans and Programmes. Official Gazette. 2004. No. 130-4650.

27. Rowe, G., \& Frewer, L. J. (2005). A typology of public engagement mechanisms. Science, Technology, \& Human Values, 30(2), 251-290. https://doi.org/ $10.1177 \% 2 F 0162243904271724$

28. Schlossberg, M. A., \& Shuford E. (2005). Delineating "public" and "participation" in PPGIS. URISA
Journal, 16(2), 15-26. Retrieved from https://core.ac.uk/download/ pdf/36679952.pdf

29. Skorupskaitè, K., \& Junevičius, A. (2017). Waste Management Policy Development in Lithuania Applying Circular Economy Model. Practice of Public Policy and Administration, 16(1), 91107. https://doi.org/10.5755/j01. ppaa.16.1.18016

30. Smalskys, V., Stasiukynas, A., Gavkalova, N., \& Lasevičiūtè, U. (2019). Problems in managing the implementation of education policy in Lithuania: The role of small municipalities. Revista Espacios, 40, 11. Retrieved from http://www.revistaespacios.com/ a19v40n26/19402611.html

31. Tang, Sh. Y., Tang, Ch. P., \& Lo, C. W. H. (2005). Public participation and environmental impact assessment in Mainland China and Taiwan: political foundations of environmental management. Journal of Development Studies, 41(1), 1-32. https://doi.org/10.1080 100220380420000276554

32. The Statute of the Seimas of the Republic of Lithuania (1999). Official Gazette. No. 5-97.

33. Tugov, A., Eskin, N., Litun, D., \& Fedorov, O. (n.d.). Ne prevratit planetu $v$ svalku [Not turning the planet into a landfill]. (In Russian). Retrieved from https://www.nkj. ru/archive/articles/10577/

34. Walker, G. B., \& Daniels, S. E. (1997). Collaborative public participation in environmental conflict management: an introduction to five approaches. Proceedings of the Fourth Biennial Conference on Communication and Environment edited by Senecah SL, Syracuse, NY, USA. https://doi. org/10.3389/fcomm.2019.00002

35. World Bank Group (1997). Utility regulators. Decision making structures, resources, and start-up strategy. Retrieved from http:// documents.worldbank.org/curated/en/174021468763755326/ Utility-regulators-decision-making-structures-resources-and-startup-strategy 